\title{
Values, Facts and Methodologies: A Case Study in Philosophy of Economics
}

\author{
By: Thomas Uebel
}

Attempts to distinguish facts and values in social science and theorizing about social science are met with considerable skepticism nowadays. My point will be to urge caution with regard to such global skepticism by showing by example that even in a debate in an area that is particularly vulnerable to value bias it is sometimes possible to assess arguments on a value-neutral basis.

My case study concerns a notorious episode in twentieth century political economy, the socialist calculation debate between Ludwig von Mises and Otto Neurath (itself but one episode of a both older and longer lasting dispute). I will show that it can be argued that, despite the prima facie plausible claim by Mises to have become the victim of ideological prejudice, it is possible to adjudicate the dispute on more objective, namely epistemological and methodological, in short "procedural" grounds.

Today, of course, political economy is widely recognized as a normative discipline, so one might not expect a resolution of such an argument at all. But just in this seeming incongruity lies the interest of the case at issue. Given that in Mises's hands the debate pertains to a putative impossibility result, there is a factual element to be assessed: it cannot be argued that it is all a matter of perspective. Yet at the same time, the impossibility result had policy implications so naturally its presuppositions are under particular scrutiny. So we are here presented with a case where the policy conclusions that can be legitimately drawn from a scientific investigation depend for their force on whether the methdodological framework employed by that discipline is acceptable-and this raises the spectre of scientific methodologies being chosen or rejected for political reasons. My resolution of this quandary-in this instance-turns on the often overlooked fact that this episode of the socialist calculation debate does not only illustrate the problem of the possibility of objective social science, but also involves the doctrine of the separation of the natural sciences from the Geisteswissenschaften.

The talk will develop three hypotheses. The first hypothesis is that the separation of the distinctive methodologies and/or ontologies of the natural and social sciences has equally important rootsbesides the work of Dilthey and Windelband-in the Methodenstreit, the methodological dispute between the so called German Historical School headed by Gustav Schmoller and the Austrian School of Exact Economics led by Carl Menger. The second hypothesis is that the self-segregation of some economists as Geisteswissenschaftler plays a central part in how arguments in the debate between Mises and Neurath were-and are to be-evaluated. The third hypothesis is that the issue was resolved-in so far as it was resolved at all-only for the price of a significant change in how the antisocialist calculation argument was put, namely by removing its dependence on its geisteswissenschaftlich foundations.

What did Mises' allegiance to Geisteswissenschaft amount to in this debate? Mises' claim in 1920 was that "rational economics" was impossible under the conditions of marketless or even market-restrained socialism. Essential to his argument was a particular conception of the rationality of economic agents and that conception in turn was derived from what he deemed purely a priori determinations of principles of rationality. With this argument in place, Mises denounced the opposition of willful rejection of his a priorist methodology on nothing but an ideological basis. Now Neurath did indeed reject Mises' methodology and as a later logical positivist was happy to accuse any recourse to Geisteswissenschaft as reactionary ideology under a methodological guise. Thus the stage was set for the kind of a seemingly 
irresolvable clash of values that we nowadays regards as definitory of political economy.

Nowadays, however, it is also held that the socialist calculation debate-at least as far as it concerned the marketless socialism argued for by Neurath in the German revolution of 1918/19 (there are other versions on offer nowadays where the case is by no means as clear)-was resolved and that it was so on factual grounds. Suppose that is so. I will show that what made it possible to move the argument outside of the contested ambit of politically motivated methodologies vs. methodologically motivated politics was a change in argumentative strategy on the part of anti-socialists. That resolution was achieved by Friedrich August von Hayek's later refashioning of Mises' calculation argument in 1938-45. Even though Hayek's argument is in many respects continuous with von Mises', it differs in precisely this respect that reliance on geisteswissenschaftliche methodology was no longer essential and that its logic was readily intelligible to thinkers of more empiriccal orientations.

In sum: here an instance of the perennial problem of social science-vs.-ideology was "resolved" (albeit only to the debatable extent of what was resolved: just how much socialism has been shown to be "impossible" remains an issue of contention) not by appeal to a universal vademecum, say a more or less crude application of Max Weber's demand for the value neutrality of social science (which in his hands though was not at all unsophisticated) by ruling out all value judgements in science, nor by a blanket acquiescence into value-ladenness and a whistful abandonment of the idea of objectivity in social science, but notably by careful attention to particulars of the case and the procedures of establishing intersubjectively valid truth claims.

\section{Literature:}

Kincaid, Dupre, Wylie (eds) Value-Free Science?, Oxford 2007.

Hayek (ed) Collectivist Economic Planning, London 1935 (material orig. 1902-1920).

Mises, Socialism, London 1936 (orig. 1922, 2nd ed 1932).

Mises, Epistemological Problems of Economics, New York 1960 (orig. 1933).

Neurath, Empiricism and Sociology, Dordrecht 1973 (material orig. 1918-1928).

Neurath, Economic Writings, Dordrecht 2005 (material orig. 1913-1925).

Weber, Methodology of the Social Sciences, New York 1949 (material orig. 1904-1917) 